\title{
ALEXANDRE GALÍ AND THE HISTORY OF INSTITUTIONS AND THE CULTURAL MOVEMENT INCATALONIA
}

\author{
Josep Monserrat (10) \\ (Faculty of Philosophy, Universitat de Barcelona) \\ jmonserrat@ub.edu
}

\begin{abstract}
In the historiography of Catalan culture, both the external continuity of the historiographical reflection and the internal discontinuity of such "reflections" are surprising. The History of institutions and the cultural movement in Catalonia (1900-1936) by Alexandre Galí is perhaps a good example of this.
\end{abstract}

Keywords: Alexandre Galí, Catalan Cultural History (1900-1936), Culture Concept

Acknowledgements: Project IEC PRO2018-S05. Models del dret i la filosofia política catalanes: semàntica de les doctrines juridicopolítiques del pactisme en les seves diferents fases [Models of Catalan political philosophy and law: Semantics of pactmodel driven political and legal doctrines at their different stages].

Disclosure statement: No potential conflict of interest was reported by the authors.

License: This work is under Attribution-NonCommercial-NoDerivs 3.0 Unported (CC BY-NC-ND 3.0) http://creativecommons.org/licenses/by-nc-nd/3.0/

Suggested citation: Monserrat, J. (2019-2020). “Alexandre Galí and the History of Institutions and the CulturalMovement in Catalonia”, Journal of Catalan Intellectual History 12: pp. 118-125 DOI: 10.2478/jocih-2019-0010

(C2021, Journal of Catalan Intellectual History 


\section{ALEXANDRE GALÍ (1886-1969)}

Alexandre Galí's work has not elicited a great deal of academic reflections, despite his undisputed importance and the extent and quality of his written work. Although more often debated than quoted, and with some of it still unpublished, a comprehensive evaluation of his work remains to be done. He is often studied within the field of the history of education, in which he rightly features as one of the principal figures in the revival of Catalan pedagogy who has been the perfect role model throughout the twentieth century. However, he has not attracted much attention until now, not in the field of historiography (despite his undeniable contribution) nor philosophy, although there are signs that that will change. Alexandre Galí was part of the "political structures" of Enric Prat de la Riba's political project and he remained completed marginalised when he returned from exile in the 1940s. His clandestine intellectual endeavour was not published, in part, until the 1980s but it did not reach beyond the personal connections which he had at the time.

Alexandre Galí was born in the mountain village of Camprodon on 11th April 1886, the second of seven siblings. His family worked in the livestock trade and politically speaking they were liberalists. When he was eleven years old his father died and he went to live with his uncle Bartomeu in Barcelona. This event had a decisive impact on his career. His uncle was married to one of Pompeu Fabra's sisters, and the two brothers-in-law managed an educational establishment in Barcelona, called the "Escola Politècnica" ("Polytechnic College"), a prestigious centre renowned for its commitment to innovation. His links with this family introduced the young Alexandre to the world of the Catalan Renaixença. He was the protégé of his uncle and Pompeu Fabra until hewas 14 years old. Although on the one hand his parentage allowed him to become personally acquainted with artists, writers, painters and the turmoil in the world of cultural "modernism", his financial status made it necessary for him to immediately start earning a living from 14 years of age, initially as a shop assistant. From that time on, he began teaching himself — on the one hand thanks to the access that his adoptive family afforded him to the immerging cultural world of Barcelona, and on the other hand thanks to the cultural work of the CADCI union. His pedagogical work began at Joan Bardina's "Escola de Mestres" (1909-1910), where he intended to enrol as a student and was ironically put in charge of teaching Spanish grammar and literature. After that, he took charge of the Escola Vallparadís in Terrassa (1910-1915) where his teaching genius came to the fore. Galí devised a "live school" where children were not driven by prizes or punishments but rather they were taught to be responsible for their actions. His methodology shocked so-called "decent people": it was the school of natural discovery, of a liberal and responsible framework within which Catalan was naturally the language used. Special importance was also given to the physical and artistic education of the pupils.

As a result of this innovative endeavour, a crucial turning point occurred in his life story. It was in 1913 during a visit to his pioneering educational establishment that the then President of the Province of Barcelona, Enric Prat de la Riba, noticed him and later requested him as "Consell de Pedagogia" for the Mancomunitat de Catalunya. In the "Consell de Pedagogia" Galí held the post of secretary from 1915 until the beginning of dictatorship of Primo de Rivera (1924).

The Mancomunitat pedagogy, a civil servant of the Generalitat. At the peak of his career, he 
married Josefa Herrera, a primary school inspector, and they had the first four of his five children. Also during this stage of his life, he formed a close partnership with Eugeni d'Ors. Given his position and capabilities, Galí collaborated vigorously in the educational work of the Mancomunitat, as Director of "L'Escola d'Estiu", Director of "Estudis Normals" and Director of the Mancomunitat of Catalonia's "Escola Montessori". He also served as general manager of the "Universitat Industrial". All of these posts were in addition to that of "Consell de Pedagogia" and with no salary increase. Overall, his organizational skills were engaged on all fronts where the Mancomunitat had jurisdiction, namely in primary and professional education. His work from this period continues to fuel pedagogical renewal and polytechnic teaching in the University to this day. Galí founded and managed the Butlletí dels Mestres, and he took over the management of all pedagogical publications in the Mancomunitat, of the Minerva collection and of the Quaderns d'Estudi magazine after the d'Ors crisis. It is from this period that his relationship with the Faculty of Sciences at Geneva University can be dated, as well as his participation in the Moral Education Congress of 1922 and his long ongoing relationship with Jean Piaget. ${ }^{1}$

With the emergence of the dictatorship of General Primo de Rivera a purging of the Mancomunitat's civil servants was undertaken. Taking advantage of the civil servants' collective complaint over the unlawful attack against psychology professor Georges Dwelshauvres, Alexandre Galí, who then stood down from his post, began the quest to rescue the pedagogical experience of the Graduate School and, in agreement with the pupil's parents who funded the new school, Galí would preside over the Technical Commission of the "Associació Protectora de l'Ensenyança Catalana" and direct the recently founded "Escola Blanquerna", the best scholastic experience in primary education of the first half of the century (1924). His role as director was not merely one ofmanagement: his passion was education and he dedicated a large portion of his time to teaching. His direct contact with the profession fuelled his scientific work on teaching in general, his manuals on language teaching, used to this day, and his investigation of bilingualism and of school work assessment which warranted translation into French in Geneva ${ }^{2}$. He attended various conferences and in Lyon he presented his work on children's theatre using pieces that children had written themselves. He organised "Cursos Tècnics de Pedagogia" affiliated with the Faculty of Sciences at Geneva University which were conducted until 1930, and subsequently under the name of the Province of Barcelona's "Seminari de Pedagogia".

With the declaration of the Republic, he was named secretary general of the Province of Catalonia's "Consell de Cultura", a post which he held without stepping down from managing the "Escuela Blaquera". During those years, his work was out of the limelight, staved off by the new left-wing politicians of the day due to the prominent role he had played in the Mancomunitat. Branded a conservative, they took advantage nevertheless, of his calibre in multiple assignments, which saw him appointed as general secretary of the Council for Culture, but ousted from the directive core of the pedagogical organization. He was replaced by Joaquim Xirau, a lecturer at the University of Barcelona, which in turn organised a Pedagogical Seminar at the University. Xirau's political views put him in a better position to succeed in his determination to control the education system and Galí was relegated into the background. Without a doubt, the

\footnotetext{
${ }^{1}$ Alexandre Galí was one of the founders of the first Societat Catalana de Filosofia (1923).

${ }^{2}$ Galí participated in the International Commission on Bilingualism, which was drawn from international pedagogy congresses.
} 
vicissitudes of that time were not to his liking, however, during the war he maintained a position of absolute loyalty to the legitimate government and as shown throughout his intellectual output, in his view it served to provide a certain continuity after $29^{\text {th }}$ July 1936.

The revolutionary council disassembled the "Consell de Cultura" and Galí only remained in the Catalanlanguage department and took up a professorship of Language Teaching Methodology at the University of Barcelona, which at that time operated under its own regulations as an autonomous university. Despite having his life threatened repeatedly, he did not run away, even when he had the opportunity to, for example when asked to carry out a visit to Paris in 1937. His wife was dismissed from her post as school inspector, a dismissal that would be repeated again after the war. Galí continued to practice his profession at the Blanquerna School until the day before the fall of Barcelona, when he then was forced to flee the country that same day. He sought exile in France where he could earn a living running a Quaker colony. His state of affairs is tragic: his wife and three small children return to Barcelona. The two eldest children find themselves taken to concentration campsin southern France for having served as reserve officers for the republican army. After that, they are taken to Cuba and then Mexico. Alexandre Galí finds himself alone. His wife, forcibly displaced to Huesca, stripped once again of her job as inspector, one child in the tuberculosis hospital in Puig d'Olena, and the two smaller ones with relatives in Barcelona or in a hostel. Eventually, he returns to Barcelona towards the end of 1943 but still on his own and living clandestinely. With no possibility of regaining his job as a civil servant, and an indefinite ban on any teaching position, he survives on translating work from English for various publishers, without taking a rest, and visiting his son who is suffering from tuberculosis at the weekends. He finally finds a job with the publisher Spes, and then Bibliograf, working on the mammoth task of dictionaries and encyclopedias, as well as the translations, working anonymously in most cases. His son Salvador dies of tuberculosis in 1945. Shortly thereafter, certain consciences are stirred and his wife is allowed to return to Barcelona, but without returning her to her position: it is now 1946. It is at this moment that a fortunate assignment will transform the defeated education system civil servant into an adventurous academic that has still not been properly recognised. An underground organisation gave Galí 30, 000 pesetas to work on a project to preserve the memory of institutions that had been destroyed.

Following the publication of a Latin-Spanish Spanish-Latin dictionary, Galí suggested to Spes publishers that they produce a Spanish grammar book in Catalan, using the monetary donations from the Minerva Foundation. In the words of his son: “A history of Catalonia's cultural struggles from 1900 to 1936 . He was more qualified tocarry it out than anyone else due to the positions that he had held, which had brought him into contact with all manner of cultural initiatives." It would not be far-fetched to say that with this commission, which extended over 5 years and gave rise to the material for twenty-three volumes of his opus magnum, Alexandre Galí brushed withgreatness. We will go on to discuss this further.

His investigations into the field of philosophy from 1951 onwards were related to the superiority of human moral facts and he began a series of works on $18^{\text {th }}$ century Catalonia from a historical perspective, beginning with a case study on Rafael d'Amat, baron of Maldà. This investigation into the causes of Catalan decadence tied in with other studies about painting and art in general. From then on, his connections with Jaume Bofill and Jaume Vicens Vives, lecturers at 
the University of Barcelona on metaphysics and history respectively, were deepened.

In March 1954, he received a tribute from former pupils. From that time on, various new projects were started todevelop educational facilities that tried to regain the renewed pedagogy from before the Republic. Alexandre Galí was in demand for all of these efforts and he collaborated decisively and freely gave of his time from his own home, but which crucially soon revealed that there was a profound lack of anthropological ideas sustaining the attempts to create new educational facilities. From 1959 to 1969 , his records contain the preparation materials for almost two hundred sessions, courses, lessons, conferences and more than forty educational centres, in addition to the individual consultations and workshops held at his house. His academic work at that time, which deserves a much more in depth study, was concentrated on a sustained effort against mass education and in favour of education based on freedom and adult human responsibility. In the curriculum that he prepared himself for his entrance as a member of the "Institut d'Estudis Catalans" in 1969, he maintained that his recent pedagogical publications and his campaign had not been grasped correctly because they were beyond the scope of the present time.

Alexandre Galí continued his work at the Bibliograf publishers until March 1969. He died on March $29^{\text {th }}$ of that same year. After his death, his poetic works were discovered, previously unknown up until that time even by his family. His family protected this wealth of material until such a time as circumstances could allow for its publication. Thanks to their efforts, from 1981 onwards the publication of his works began with the twenty-three volumes of The History of Institutions and the Cultural Movement in Catalonia 1900-1936, its final edition in 1985, and subsequently the four volumes of Escrits polítics, Escrits històrics, Escrits pedagògics, Darrers escrits.

\section{THE HISTORY OF INSTITUTIONS}

Alexandre Galí dedicated five whole years to the writing of his magnum opus. Circumstances did not allow him free access to the necessary information, which in more than one instance involved sensitive information. His former position had afforded him a privileged position from which to understand the cultural movement in its entirety. His intelligence and capacity for producing extraordinary work elucidate the workmanship of the results. A lot of information had to be researched in secret and, as can often be noted, oral reports from principalparticipants is used to substitute documentation that was destroyed in attempts at cultural destruction.

In the introduction to The History of Institutions and the Cultural Movement in Catalonia 1900-1936, the author defines what culture is, according to its origin. This definition guided the writing of all twenty thematic books as well as the three introductory volumes, and a further volume reserved exclusively for appendices.

After analysing the word 'culture' according to dictionaries in different languages and after outlining briefly the philological history of the term, Alexandre Galí concludes that in the reference works he consulted there is a tendency to define culture as an individual ornament and as something that is received and not something that is created, a definition applicable to people who, in neither Catalan nor Spanish have produced culture, being unaccustomed to collaborating 
with others to create it but instead limiting themselves, with virtual greed and determination, to taking advantage or of making use of it as an individual addendum. Such definitions are, according to Galí, the poorest possible definitions of the term culture.

In contrast, for the author, culture is something that is created, individually and collectively, and which is created willingly. For that reason, culture is the result of a mentality which crafts a cultural programme from the very first wilful act and in line with its historical context.

Firstly, one must study what he calls "cultura profunda" which he defines as the capacity, the abilities and the way of reacting that people have when faced with major spiritual or moral issues which the western world is focused on. In other words, in this study culture is that which is acquired and assimilated from an active point of view, that which is put in accordance with. The creators and the creations are not the principal object of study but rather they are elements of demonstration or proof. It is not, therefore, a history project which Alexandre Galí proposes, but rather collective psychology based on the elements that constitute history.

Institutes should be studied from this perspective and evaluated according to an ideal or a model. Galí is extremely critical when evaluating movements and institutes and the ideas that they have given rise to. We frequently find categories such as 'advanced' or 'backward' in his work, indicating the successes and failures in terms of the overall framework of contemporary European problems and tendencies. Such grading assess how the institute, or the mentality which it has engendered, compares with the model to which it aspires: "In this way, when the reader sees that we criticise or insist on reporting deficiencies or errors in whichever activity we examine, we give them licence to suspect that on certain occasions we, in our innermost feelings, are capable of considering more humanly perfect and therefore happier, a nomadic community that has resolved the complex question of the meaning of life."

Index

Introduction [The concept of culture]

Book I: Language - Entities of Propagation and Defence

Book II: Primary Education

Book III: Secondary Education

Book IV: Technical-industrial Education and technical-manual education of art and trades

Book V: Technical-artistic Education and the fine arts. Artistic movements

Book VI: Education in Agricultural Services

Book VII: Economics and Administrative Education

Book VIII: Institutions for the education of women

Book IX: University Education

Book X: Institutions of popular culture

Book XI: Public libraries and the literary movement 
Book XII: Music, theatre, cinema

Book XIII: General, technical and specialised libraries. Bibliography and Bibliophilia

Book XIV: Archives and libraries

Book XV: Technical-administrative services

Book XVI: Scientific academies and societies

Book XVII: The Institute of Catalan studies

Book XVIII: Foundations, prizes, scholarships and allowances

Book XIX: Conferences and scientific and philosophical movements

Book XX: The co-operation of the Church in the cultural movement in Catalonia during the 20th century.Epilogue of the entire work

This brief presentation of Alexandre Galí's greatest work has merely outlined his organizational structure. Perhaps it is enough to shown that he deserves more recognition. The task of preserving historic memories for a written work which is sub specie aeternitatis whilst undergoing a period of persecution, was carried out through costly and sensitive documentary research, focusing on oral testimony from the silenced main characters and the main character's own memory. He produced a masterpiece of language, adopting the most fitting style for his purpose: clarity and a vast array of nuances, as is appropriate for the task of studying culture and institutes: from harsh criticism to measured praise, from intelligent irony and a certain dose of humour, he remains mindful of the potential for improvement amongst his compatriots even after confirmation of defeat and more serious collapses.

\section{REFERENCES}

Casanovas, P. and Monserrat, J. 2004. "El projecte Philosophy and Catalan Intellectual History". Comprendre, 6 (2): 147-164.

Díez Garcia, M. 2016. Alexandre Galí i la filosofia de la història. Estudi de materials inèdits. Universitat deBarcelona: Tesi doctoral dirigida per Josep Monserrat Molas, setembre de 2016.

Galí, A. 1928. La mesura objectiva del treball escolar. Barcelona: Neotipia [reedited: Vic: Eumo, 1984].

Galí A. and Herrera, J. 1932. Activitat i llibertat en educación. Quaderns dels cursos lliures de pedagogia, Barcelona: Atenes.

Galí, A. 1954. Rafael d'Amat. Baró de Maldà. Barcelona: Aedos.

Galí, A. 1964. Una hipotètica revolta d'uns mestres hipotètics. Perpinyà: Proa.

Galí, A. 1967. Mirades al món actual. Primera sèrie de vuit assaigs. Barcelona: Arc.

Galí, A. 1980-1985. Història de les institucions i del moviment cultural a Catalunya: 1900-1936 (23 Vol.).Barcelona: Fundació Alexandre Galí.

Galí, A. 1989. Darrers Escrits (1967/1969). Barcelona: Fundació Alexandre Galí. Galí, A. 1990. 
Escrits Pedagògics (1952-1966). Barcelona: Fundació Alexandre Galí.

Galí, A. 1990. Escrits Polítics. Escrits Històrics (I). Barcelona: Fundació Alexandre Galí. Galí, A. 1991. Escrits Històrics (II): Art, luxe i esplai, Barcelona: Fundació Alexandre Galí.

Galí, A. 2004. Pensament i Filosofia a Catalunya (1900-1936). Ed., Pere Lluís Font and Josep MonserratMolas. Barcelona: Societat Catalana de Filosofia-Institut d'Estudis Catalans.

Serra, X. 2010. Història social de la filosofia catalana. La Lògica (1900-1980). BarcelonaCatarroja: Afers. Serra, X. 2013. La filosofia en la cultura catalana. Barcelona-Catarroja: Afers. 